\title{
"The Great Sophism of All Sophisms": Colonialist Redefinition in Bacon's Holy War
}

\author{
CRAIG M. RUSTICI
}

$\mathrm{J}$

ames Bonwick, a nineteenth-century historian of Tasmania, notes that when "Dr Wardell of Sydney defended an Englishman charged with the murder of a Black, he argued from Lord Bacon, Pufendorf, and Barbeyrae, that savages who fed upon human flesh (as the Australians were by him assured to do), were proscribed by the law of nature; consequently it was no offense to slay them." Ironies as well as horrors surround this brief report. In his argument, Dr. Wardell, presumably Robert Wardell, founding proprietor of the weekly Australian, alluded not to one of Bacon's legal treatises or judicial decisions but to an incomplete dialogue Bacon composed in 1622 after his fall from high public office, not to an opinion Bacon articulated directly but to one he ascribed to a fictional character, and, I will argue, not to an opinion Bacon wished to endorse but to one he wished to repudiate. $^{1}$

In this dialogue, An Advertisement touching an Holy War, Bacon assembles six interlocutors with different occupations and different religious convictions. The interlocutors agree to discuss just war, and they devote particular attention to the Spanish conquest of America and to a projected war against the Turks. One interlocutor, Eupolis, projects an elaborate structure for their discussion, and each agrees to explore a particular point. In the course of this discussion, they consider secular and religious justifications of war and debate the nature of non-Christian, non-European cultures. The dialogue breaks off in the first of the six projected discourses after the interlocutor Zebedaeus elaborates a mostly naturalistic defense of the conquest of America and of a war against the Ottoman Empire.

By relating the Holy War to Bacon's other works and his career-long opposition to the Spanish empire, we can see that Wardell misread Bacon's intention. In this dialogue Bacon exploits his knowledge of sixteenth-century 
moral and legal debates over the Spanish conquest of America to challenge Spanish colonial ideologies, particularly colonialist constructions of the cultural Other and colonialist definitions of natural law and of charity. Far from endorsing Zebedaeus's justification of the murder of savages, Bacon means to challenge it and does so even in the dialogue's incomplete form by basing that defense upon propositions that he repudiates in other texts. When he "argued from Lord Bacon" to defend a murderous English colonist, Wardell mistakenly cited an opponent rather than a defender of colonial violence.

\section{Zealous Readings}

Like Wardell, almost all the critics who discuss the Holy War identify Bacon's views with those of Zebedaeus, the interlocutor who defends the lawfulness of both the Spanish conquest of America and of a projected war against the Turks. ${ }^{2}$ However, even a quick glance at how Bacon characterizes the dialogue's interlocutors warns us to avoid too facile an identification of Bacon and Zebedaeus. As Bacon lists the dialogue's interlocutors he characterizes Zebedaeus as a "Romish Catholic Zelant [Zealot],", an unlikely spokesman for a writer who was wary of both zeal and Catholicism. ${ }^{3}$

Moreover, Bacon adjusted his characterization of the interlocutors in the dialogue's English and Latin editions to put distance between each edition's projected audience and Zebedaeus. In the English text Bacon identifies the religious views of only three of the six interlocutors: Zebedaeus, "a Romish Catholic Zelant," Eusebius, "a Moderate Divine," and Gamaliel, "a Protestant Zelant." He characterizes the remaining three according to profession alone: "Martius, "a Militar[y] Man," Eupolis, "a Politique," and Pollio, "a Courtier." English Protestant readers are free to assume that the reformist zealot and moderate divine as well as the politique, courtier, and perhaps even the hawkish soldier are, like themselves, Protestants. Zebedaeus is the odd-manout, the religious alien. Anglicans might fear Gamaliel's reformist extremism, but there is little of Gamaliel in the dialogue to disturb them. In this uncompleted text he utters only a single sentence, whereas Zebedaeus orates roughly half of the dialogue. In the English edition, Bacon thus uses implicit assumptions about religious affiliation to distance English Protestant readers from Zebedaeus.

When preparing Latin translations of his texts, Bacon was sensitive to the Catholic sentiments of many Continental readers. He reports to King James that during the translation of The Advancement "I have also been mine own Index Expurgatorius, so that it may be read in all places." ${ }^{4}$ Even if the 
Holy War escaped the Inquisition's index and Continental Catholics were permitted to read it, they might align themselves automatically with the dialogue's only explicitly Catholic interlocutor, Zebedaeus. By shifting the theological spectrum in the dialogue's Latin translation, however, Bacon ensures that they do not. To the list of interlocutors, he appends the sentence "Omnes praeter Gamalielem Romano-Catholici" (All but Gamaliel are Roman Catholics). Thus in the Latin edition Zebedaeus is only one of five explicitly Roman Catholic interlocutors with whom Continental Catholics might sympathize. Further, by designating Eusebius "Theologus Orthodoxus et moderatus" (orthodox and moderate theologian), Bacon implies that even within Roman Catholicism Zebedaeus's zeal is nearly heterodox. Bacon thus emphasizes the similarities between Zebedaeus and the dialogue's other implicitly heterodox zealot, the Protestant Gamaliel (191). ${ }^{5}$ In the Latin translation, then, Bacon alienates the sympathies of Continental Catholics from Zebedaeus, pairing him with Gamaliel, the zealot of few words and heterodox theology.

Among the readings that identify Zebedaeus as Bacon's spokesman, the most useful is J. Max Patrick's exploration of the personal, cultural, and political contexts for a Baconian proposal for war against the Ottoman empire, yet ultimately, I find that even Patrick does not contextualize the Holy War thoroughly enough. ${ }^{6} \mathrm{He}$ contends that Bacon pursued two objectives as he composed the Holy War: the recuperation of his political fortunes and the pacification of the English body politic. According to Patrick, in 1622 Bacon still hoped to regain the royal favor he lost after his impeachment from the chancellorship. Consequently, Bacon designed his dialogue to appeal to an interest in Turkish war that the admittedly "dovish" James I had expressed thirty-seven years earlier when he wrote a heroic poem to celebrate the Christian victory at Lepanto. However, in the dedicatory epistle to Lancelot Andrewes, Bacon does not characterize the Holy War as a literary oblation to his king. Rather than assert his desire for political recovery, Bacon suggests that an even more precipitous fall might follow such a recovery. Cautioned by that prospect, he renounces politics in favor of literature. In his remaining literary projects, he intends to address his duty to "the general good of men" and to his own country, but he omits his duty to the monarch (186). Of course, Bacon may have composed this dedication after political events rendered his original intention obsolete; nonetheless, Bacon's representation of his authorial intention conflicts with Patrick's.

Concerning Bacon's second objective, Patrick reasons that the former Lord Chancellor recognized the crown's growing financial difficulties and its 
deteriorating relations with Parliament and consequently "urged consideration of the time-tested practical cure for internal dissensions - a popular external war which would unite all in common endeavor and enthusiasm" and secure parliamentary subsidies. Bacon would have preferred a war with Spain, "[b]ut in 1622 while negotiations for the Spanish match were being renewed, Bacon had to couch his case otherwise [that is, as holy war against the Turks]."7 But Bacon had good reason to doubt whether an Anglo-Spanish campaign against the Turks would quiet internal dissension and unite the English populace. In 1617, Bacon served on a commission of Privy Councillors which interviewed London merchants and sea-captains concerning the suppression of North African pirates. When the commissioners proposed an international alliance against the pirates, the merchants welcomed coordination with the Dutch but certainly not with the Spanish: "they supposed the King of Spain did not really desire the suppressing of the pirates, and therefore would rather hinder than further it...". 8 After the commissioners convinced the merchants that the pirates harassed Spanish as well as English and Dutch shipping, the merchants, sea captains, and commissioners agreed that James I should solicit Spanish financial assistance and access to Spanish ports but nothing more. In 1617 even direct self-interest could not drive these English citizens to embrace a full military alliance with Spain. As we shall see, in 1622 an Anglo-Spanish alliance against the Turks would have been even less popular.

As if he recognizes difficulties in this argument, Patrick concludes his essay equivocally. Initially, he asserts that although Bacon "does not specifically advocate an Anglo-Spanish holy war alliance in the Advertisement, he clearly intended to do so" (my emphasis). Eventually Patrick questions whether Bacon hoped for "a war in Europe's furthest corner" but concludes that Bacon "probably agreed with his character Zebedaeus that a war against the Turks is lawful..." (my emphasis). ${ }^{9}$ By comparing the Holy War with Bacon's other discussions of religious war, we can minimize this interpretative uncertainty and distinguish Bacon's views from Zebedaeus's.

As Patrick notes, the pro-Zebedaean reading, which identifies Bacon's view with Zebedaeus's, is consistent with one of Bacon's texts. In March 1617, Bacon wrote to Sir John Digby, the royal emissary who was negotiating a marriage between the Prince of Wales and the Spanish Infanta. He instructed Digby to raise several points during his negotiations, including that the Spanish match "may be a beginning and seed ... of a holy war against the Turk." ${ }^{10}$ However, we must explore the context of this remark before using it to explicate the dialogue Bacon wrote five years later. 
March 1617 was a heady time for Bacon. On March 2, he first learned in detail of the negotiations for the Spanish match when James I briefed a select group of privy councillors which included Bacon. At the time of the briefing, the project was well-advanced, and after a second conference on March 7 the councilors agreed that negotiations should proceed. On March 5, the King accepted the resignation of Thomas Egerton, Lord Ellesmere, his long ailing Lord Chancellor and Lord Keeper, and on March 7, he appointed Bacon Lord Keeper, thus installing him in the office Bacon's father Sir Nicholas had held a generation earlier. The following January, James I would also appoint Bacon Lord Chancellor, and Bacon's career would reach its pinnacle. Having just received a high office and with another tantalizingly available at Chancery, Bacon may have felt obliged to serve James in the newly announced royal project despite his reservations concerning the Spanish match. ${ }^{11}$ On March 23, he sought to advance that project by submitting to James an instructional memorandum to guide Digby's negotiations at the Spanish court.

The royal briefings revealed that marriage negotiations had collapsed in the past when the Spanish demanded unreasonable religious concessions, like the Prince's conversion to Catholicism. Bacon, who had observed the tropes of Spanish diplomacy for years, offers Digby a strategy for avoiding such a collapse: divert the Spanish from discussions of religious differences by "beat[ing] upon" pious enterprises in which Catholic and Protestant states could collaborate, "therewithal to fill up the spaces of the active part of your negotiations." 12 Prominent among these enterprises is the old Spanish favorite: a holy war against the Turks. ${ }^{13}$

Bacon wrote to Digby during the Pax Hispanica, a period of Spanish retrenchment and nonaggression. ${ }^{14}$ However, by 1622 when he composed the Holy War, the Thirty Years War was underway, Spanish troops had occupied the Lower Palatinate, the patrimony of James I's son-in-law Frederick, the Count Palatine and the newly elected King of Bohemia. In 1619, in response to the opening events of the Thirty Years War, Bacon advocated an English attack on Spain. ${ }^{15}$ Like some of his contemporaries, Bacon eventually considered that the recovery of the Palatinate might become a condition of the marriage treaty; ${ }^{16}$ however, his skepticism concerning Spanish diplomacy and the advisability of a marriage alliance suggest that he did not invest great hope in the realization of this prospect. ${ }^{17}$

In light of the professional pressures that may have prompted Bacon to contribute to the marriage negotiations, the changes in the international situation between 1617 and 1622, and Bacon's doubts concerning the ad- 
visability of the Spanish match, we should not base our interpretation of the Holy War only on the letter to Digby. Certainly, the theoretical discussions of religious war that Bacon composed between 1623 and 1625 also should inform our analysis of this dialogue. ${ }^{18}$ According to Bacon, the "laws of charity, and of human society" restrict the methods Christians may use to propagate the faith (Essay III). In light of these restrictions, "offensive wars for religion are seldom to be approved, or never, unless they have some mixture of civil titles." Often as in Essay III, Bacon contrasts these Christian restrictions with Islamic authorizations of religious war:

There be two swords amongst Christians; the spiritual, and temporal; and both have their due office, and place, in the maintenance of religion. But we may not take up the third sword, which is Mahomet's sword, or like unto it; that is, to propagate religion, by war, or by sanguinary persecutions, to force consciences; except it be in cases of overt scandal, blasphemy, or intermixture of practice against the state... ${ }^{19}$

Admittedly, the exceptions that conclude this statement threaten to undermine the prohibition that begins it. As the essay progresses, however, Bacon exploits these exceptions to repudiate rather than to authorize religious violence. He contends that to murder princes, butcher people, and subvert governments, and especially to incite the common people to such actions in the name of religion is to blaspheme and to bring scandal upon the Church. Such actions transform the image of the Holy Ghost from a dove to a vulture and adorn the bark of the Church with a flag of pirates and assassins. A Christian prince must repress such blasphemy and scandal, but even his "temporal sword, is to be drawn, with great circumspection, in cases of religion." Although Bacon cautiously admits exceptions to the charitable prohibitions against religious violence, he concentrates the rhetoric of this essay upon the repudiation rather than the authorization of such violence.

Moreover, in other texts Bacon declines to claim that blasphemy or scandal perpetrated by Turks or Amerindians authorizes Christians to take up “Mahomet's sword." In Considerations touching a War with Spain (1624) he contends,

[I]n deliberations of war against the Turk, it hath been often, with great judgment, maintained, that Christian princes and states have always a sufficient ground of invasive war against the enemy: not for the cause of religion, but upon a just fear [my emphasis]; forasmuch as it is a fundamental law in the Turkish empire that they may (without any 
provocation) make war upon Christendom for the propagation of their law [Islam]...

Although Bacon claims a constant, just cause for Christian attacks upon the Ottoman empire, he bases that cause upon fear rather than religion. Unlike his literary creator, Zebedaeus does not cite Christians "just fear" of Turkish aggression to authorize war against the Turks. Furthermore, if we extend our chronological scope and consider the letter of advice Bacon wrote in 1616 to the King's favorite, George Villiers, Duke of Buckingham, we find Bacon forcefully and unequivocally repudiating violent evangelization of the Amerindians. English colonists in the New World must not injure the natives and must "make no extirpation of the natives under pretence of planting religion: God surely will no way be pleased with such sacrifices." ${ }^{20}$ Bacon, unlike his literary creature, refuses to authorize war against the Turks or the Amerindians "simply for the propagation of the faith" (204). ${ }^{21}$

Not only does Zebedaeus promise to justify wars on religious grounds; he also elaborates a naturalistic defense of campaigns against the Turks and the Amerindians $(206-7,215)$. Once again, literary creature and creator are at odds. Three contentions within Zebedaeus's defense of such secular wars conflict with views Bacon articulates in other texts. I will examine Zebedaeus's argument in detail in the following section. Here, I intend only to identify the points at which it conflicts with Bacon's views and the methods through which Bacon foregrounds those conflicts.

First, Zebedaeus bases his defense of the conquest of America and of the proposed war against the Turks upon Aristotle's theory of natural slavery (Politics 1253-55). He contends that the law of nature authorizes the oppression of those whom Aristotle designated natural slaves. According to Bacon, however, the law of nature authorizes liberty rather than slavery. In the Case of the Post-Nati of Scotland (1608), Bacon adopts Justinian's theory of slavery (Institutes 1.2-5) rather than Aristotle's. ${ }^{22}$ By nature all men were free - "natura omnes homines erant liberi." Positive law rather than natural law institutes slavery, and "servitude or villenage doth cross and abridge the law of nature." ${ }^{23}$ Concerning the naturalness of slavery, Bacon and Zebedaeus flatly disagree.

Moreover, whereas Zebedaeus defends the conquest of America by positing the naturalness of slavery, Bacon repudiates the conquest by positing an antithesis between slavery and Christianity. In an early piece of antiSpanish rhetoric, he observes that "the Christian religion generally brought enfranchisement of slaves in all places where it came" but that "the poor 
Indies... in a contrary course are brought from freemen to be slaves, and slaves of most miserable conditions." He later restates this antithesis in the less polemical context of Essay XXIX, as he asserts that slavery "is abolished, in greatest part, by the Christian law." Despite this disagreement between literary creature and creator, Zebedaeus does appear to speak for Bacon momentarily as he observes that some have designated Aristotle's theory of natural slavery "a speech of ostentation, to entitle the Grecians to an empire over the barbarians" (208). ${ }^{24}$ Of course, Zebedaeus considers that charge false. But Bacon, who saw parallels between the ancient Macedonian and modern Spanish empires and considered slavery an unacceptable pagan practice, might well consider the charge of mere "ostentation" true. Through Zebedaeus's own words, then, Bacon encourages his readers to recognize the disparity between the views of Zebedaeus and his author.

Second, Zebedaeus relates natural slavery to a theory of God in man and specifically repudiates one alternative position taken by "fanatical spirits" who claim that "the image of God is purity, and the defacement [original] sin." This claim cannot be true, according to Zebedaeus, since it implies that "Adam's sin, or the curse upon it, deprive[d] him of his rule" over creation. Instead, in Zebedaeus's formulation, original sin "left the creatures to a rebellion or reluctation." In fact, Bacon agrees with the "fanatical spirits" whom Zebedaeus repudiates. In his "Confession of Faith," he asserts "That God created man in his own image, in a reasonable soul, in innocency, in free will, and in sovereignty ... [but that] upon the fall of Man, the image of God in man was defaced" $(210,212)^{25}$. Moreover, Bacon restates this account of the fall in scientific works such as the Valerius terminus (c. 1603) and the Novum organum (1620) as he defines the scientific project in relation to humanity's postlapsarian condition. Religious faith can partially repair the loss of innocence, science the loss of dominion. ${ }^{26}$ Although, like Zebedaeus, Bacon refers to the "reluctation" of creation, he repeatedly and unequivocally asserts the loss of humanity's prelapsarian dominion over creation. ${ }^{27}$ Thus as Zebedaeus poses another hypothetical objection to his own argument, Bacon again foregrounds his profound disagreement with the views of his literary creature.

The third disparity between the views of Bacon and Zebedaeus is particularly striking. To defend further any nation's right to subdue natural slaves, Zebedaeus argues that even in the absence of formal alliances "respective to particular enemies" there exists a "natural and tacit confederation amongst all men against the common enemy of human society." That "common enemy" includes pirates, assassins, and natural slaves. This principle 
justifies, for example, ancient Rome's Second Macedonian War to liberate Greece. In Essay XXIX, however, Bacon rejects both Zebedaeus's principle and his example: "As for the wars, which were anciently made, on the behalf, of a kind of party, or tacit conformity of estate, I do not see how they may be well justified: as when the Romans made a war for the liberty of Grecia...". Once again, Bacon foregrounds his disagreement with Zebedaeus. After he posits this tacit confederation among unallied states, Zebedaeus asks rhetorically against whom this confederation is directed: "Is it against wild beasts? or the elements of fire and water?" Zebedaeus then answers, "No, it is against such routs and shoals of people" $(213,217-18)$ But I believe that in light of his scientific writing, Bacon's answer would be "yes." As we have seen, Bacon imagines science restoring part of humanity's original dominion over the created, material world. He often describes the scientific project as the conquest of nature. ${ }^{28}$ Further, for Bacon, science is an international project intended to benefit all humanity. Human beings are allied against a rebellious creation that all too often renders their lives miserable and laborious. ${ }^{29}$ Once again, the position Zebedaeus introduces, only to discount casually, is the position Bacon espouses. There can be little doubt, then, that whether he founds his argument on naturalistic or religious grounds, Zebedaeus does not speak for his author.

In fact, although none of the interlocutors consistently speaks for Bacon, the courtier Pollio resembles his literary creator at least as closely as does Zebedaeus. ${ }^{30}$ Eupolis describes Pollio as a Baconian skeptic "who hath a sharp wit of discovery towards what is solid and real and what is specious and airy" (201). Pollio's skeptical interruptions disturb not only the orderly discourse of individual interlocutors but also the consensus that Eupolis hopes to form. By pressing for more precise definitions of the religious and cultural Other, he prompts Zebedaeus and Martius to disagree over the nature of the Amerindians, and Zebedaeus and Gamaliel over the justice of the Spanish expulsion of the Valencian Moriscos.

Although the dialogue breaks off before Pollio can undertake the discourse Eupolis assigns him, Pollio emphatically asserts the conclusion he intends to reach. Unless Christendom is reformed radically, a holy war is impossible. Pollio does not specify the necessary reforms, but it seems clear that at the very least the internecine conflicts between Christian states must cease. Pollio proceeds to contend that like the philosopher's stone, the holy war is "but the rendez-vous of cracked skulls" (202). Jerry Weinberger recommends helpfully that we explicate this remark in light of Bacon's critique of alchemy. In The Advancement Bacon criticizes alchemists for the 
incongruity between the means and ends of their science (I $A$ of $L$ IV. II; II $A$ of $L$ VIII. 3). Its ends are noble, but "the derivations and prosecutions to these ends, both in the theories and in the practices, are full of error and vanity" at times they even seem "monstrous." 32 The winning of souls for Christ is a noble end, but the calamities of war and the violence of Mahomet's sword are means in conflict with that noble end. In this way, for Pollio and for Bacon, the holy war is like the philosopher's stone. Of the dialogue's six interlocutors, only Pollio voices a critique of religious war consistent with Bacon's.

\section{"Lex Charitatis"}

Rather than speak through Zebedaeus to propose or justify war against the Turks or the Amerindians, Bacon exploits the dialogue form to interrogate Spanish colonial ideologies, particularly colonialist constructions of the cultural Other and colonialist definitions of natural law and of charity. He creates interlocutors who challenge each other's contentions, and as we have seen, even after the other interlocutors fall silent and Zebedaeus begins his oration, Bacon continues this interrogation by foregrounding the conflicts between his views and Zebedaeus's. Bacon breaks off the dialogue when those conflicts between literary creature and creator are most intense as Zebedaeus redefines the prized Baconian virtue of charity.

The skeptical Pollio prompts the dialogue's first discussion of Amerindian nature and its first construction of the cultural Other. Like such modern analysts of the European conquests as Tzvetan Todorov and Stephen Greenblatt, Bacon appears to have recognized that extreme assertions of absolute difference from or absolute identity with the cultural Other contribute equally to colonialist ideology. Since the Self's humanity is hardly ever put in doubt, assertions of absolute difference usually deny the Other's humanity and consequent rights. ${ }^{32}$ As he interrupts Martius's encomium on the Spanish conquest of America, Pollio posits absolute difference between Europeans and Amerindians. As "wild and savage people [the Amerindians] are like beasts and birds, which are ferae naturae [wild natures], the property of which passeth with the possession, and goeth to the occupant [of territory]: but of civil people, it is not so." Pollio thus denies the Amerindians' humanity. Since they resemble wild beasts more closely than civil people, they lack the right to self-determination. Their conquest is just; indeed, it is of little consequence, the mere occupation of territory, and unworthy of Martius's encomium. 
Martius challenges Pollio on two grounds. First, he recognizes "no such difference amongst reasonable souls." All rational animals, all homines sapientes, however uncivil, are human beings. Second, the Amerindians are not wild and savage but at least as civil as other pagans whom Europeans have encountered. The Incas govern themselves with justice, practice monotheism, and construct "magnificent temples." The Mexicans, presumably Aztecs, govern themselves through an elective monarchy. Martius posits one essential human nature, defined by reason, and cites ethnographic data to prove that the Amerindians participate in that nature. He thus identifies the Amerindian cultural Other with himself.

Although this assertion of absolute identity is initially more attractive than the assertion of absolute difference, it also supports colonialism. Martius demonstrates as much by contending "that whatsoever is in order to the greatest and most general good of people may justify the action [including conquest], be the people more or less civil" (197-98). If the Self and the Other are essentially the same, the good for the Self is also the good for the Other, and the Self's values are universal values. ${ }^{34}$ Conquest and assimilation become matters of charity. But Martius is a soldier rather than an ideologist, and he leaves it up to Zebedaeus to elaborate his contention and to demonstrate that subjugation is to the Amerindian's "greatest and most general good."

As I noted in the preceding section, like actual colonial ideologists such as John Major and Juan Ginés de Sepúlveda, Zebedaeus bases his defense of the conquest of America and of a proposed war against the Turks upon Aristotle's theory of natural slavery (Politics 1253-55). ${ }^{35}$ Zebedaeus contends that there are some individuals or groups of people who so thoroughly violate the laws of nature and nations that they are incapable and unworthy of self-determination. They are natural slaves, and other people who observe the laws of nature and nations have natural dominion over them. Natural slaves differ from natural master as the body differs from the soul and as beasts differ from human beings. The Turks and the Amerindians are such natural slaves.

We can see the usefulness of this reasoning. If some people are innately incapable of self-determination, then subjugation is to their "greatest and most general good." Moreover, the appeal to laws of nature and nations introduces a set of universal values against which the Self can measure the good for the Other. However, the appeal to Aristotle introduces at least one difficulty for Zebedaeus. The analogy between slave and beast appears to recall a construction of the cultural Other that Pollio has already posited and Martius has 
already rejected. Consequently, Zebedaeus distances himself from this aspect of Aristotle's theory, preferring to define natural slaves primarily through their incapacity for self-determination rather than through their relation to natural masters.

To define this incapacity, Zebedaeus relates natural slavery to a theory of the image of God in man. Citing Francisco de Vitoria, he contends that all human dominion is founded upon the image of God. "Deface the image, and you devest the right." Zebedaeus defines that divine image as natural reason. Nations that deface natural reason through their fundamental laws and customs become natural slaves, nations de facto but not de jure. The laws of nature and nations permit nations de jure to conquer and subdue these mere "swarms of people."

This argument reinforces the identification between Self and cultural Other. If God created all of humanity in his own image, then there is one essential human nature reflecting that image, and the Self and the Other are essentially the same. Like Martius, Zebedaeus defines all human beings as reasonable souls. To demonstrate the good of conquest, however, Zebedaeus argues that some human beings "totally or mostly" deface natural reason.

Without precisely defining the general conditions that constitute the defacement of the divine image, Zebedaeus examines the laws and customs of specific degenerate societies. Of these societies, the Amerindians' is the most important. He does not address the Turks, apparently because Martius's charges of Turkish savagery, which Zebedaeus endorses, satisfy the needs of his argument. ${ }^{36}$ Yet Zebedaeus does cite examples, some actual and others hypothetical, of societies whose international relations violate the laws of nations or whose internal organization violates apparently natural hierarchies. He devotes his greatest attention, however, to the Amerindians.

To justify the conquest of America on the grounds he has established, Zebedaeus must challenge Martius's account of Amerindian civility and demonstrate the irrationality of fundamental Amerindian laws and customs. As evidence of that irrationality, he cites Amerindian nakedness and sorceries, as well as various Amerindian "idioc[ies]," that is, misinterpretations of European technology. Like Sepúlveda, he ultimately founds his demonstration upon Amerindian human sacrifice and cannibalism. ${ }^{37}$ According to Zebedaeus, because the Amerindians so abominably violate the laws of nature, they forfeit their right to self-determination, and that forfeiture justifies Spanish invasion.

Once again, however, Bacon invites his readers to challenge Zebedaeus's argument. By 1622, Amerindian human sacrifice and can- 
nibalism were familiar charges with a familiar rebuttal. Defenders of the Amerindians often figured Spanish violence in the New World as a form of human sacrifice. They contended that the Spanish had committed at least as many blood sacrifices as the Amerindians. ${ }^{38}$ As we have seen, Bacon equates colonial violence and human sacrifice as he repudiates the extirpation of natives: "God surely will no way be pleased with such sacrifices." Zebedaeus himself anticipates such an equation earlier in his discourse as he warns that "We must beware therefore how we make a Moloch or a heathen idol of our Blessed Saviour, in sacrificing the blood of men to him in an unjust war" $(207)^{39}$ Since Bacon does not agree with crucial contentions in Zebedaeus's justification of the Spanish conquest, he presumably would consider Spain's unjust wars in the New World such an unholy sacrifice. As if encouraging Bacon's readers to recall this common rebuttal and the earlier reference to the human sacrifices committed to an unjust war, Zebedaeus repudiates Spanish "cruelties" toward the Amerindians, even as he defends the Spanish right to "reduce" or "displant" these people.

Zebedaeus's theories not only authorize natural masters to conquer natural slaves, they even oblige them to do so. To demonstrate that obligation Zebedaeus emphasizes and elaborates elements implicit in the preceeding argument and postulates "a supreme and indissoluble consanguinity and society between men in general." The existence of a single, common creator of all humanity, which Zebedaeus's discussion of the image of God assumed, proves this "consanguinity and society," and the Judaeo-Christian account of creation further emphasizes it. Human beings are not only the creatures of a single creator, they are also the products of the same originary material, "one lump of earth," and descendants of the same two parents, Adam and Eve. "[N]o nations are wholly aliens and strangers the one to the other." Christianity in particular exhorts its followers to recognize a common human brotherhood. In other texts Bacon insists that, more than any other religion or philosophy, Christianity exalts charity. Christians must be interested in the conditions of distant peoples. The general human society Zebedaeus thus postulates opposes those individuals or groups of people who "utterly degenerate from the laws of nature." These "delinquents" cannot reform themselves: consequently, love and consanguinity oblige the rest of humanity to suppress them. Three postulates shape this colonialist ideology: the existence of one essential human nature, the identity of Self and cultural Other, and the duty to do the Other's good. Zebedaeus emphasizes each of these in his discourse's final crescendo: 
And this, I say, is not to be measured so much by the principles of jurists, as by lex charitatis; lex proximi [law of charity; law of the neighbor]; which includes the Samaritan as well as the Levite; lex filiorum Adae de massa una [law of the sons of Adam from one lump of earth]; upon which original laws this opinion is grounded: which to deny ... were almost to be a schismatic in nature $(217-218) .^{40}$

Once one postulates one true human nature, love of neighbor can become a means to empire.

In my preceeding sentence, the auxiliary verb "can" is crucial. Even seventeenth-century thinkers who embraced several of Zebedaeus's premises did not arrive at his conclusions. For example, the later seventeenth-century. German jurist Samuel Pufendorf, whom you recall Robert Wardell cited in defense of a murderous Australian colonist, was no "schismatic in nature." Like Zebedaeus, Pufendorf posits a "society between men in general." However, Pufendorf derives that society from observation of the human condition rather than from an account of human origins. Human beings cannot survive and prosper "without the help of fellow-creatures." Consequently, the fundamental law of nature asserts that every human being "should cultivate and preserve toward others a sociable attitude which is peaceful and agreeable at all times to the nature and end of the human race." 41

From a common human society Zebedaeus derives the right and obligation of some human beings to reprove and oppress other, degenerate human beings; in contrast, from a similar common human society Pufendorf derives the obligation of all human beings to respect one another. Since "no one can live a social life with a person by whom he is not rated as at least a fellow man, it is a precept of natural law, that 'Every man should esteem and treat another as his equal by nature or as much a man as he is himself.' " From the axiom of natural equality, Pufendorf further derives a corollary: his own formulation of a "lex charitatis, lex proximi." Citing authorities as diverse as Thomas Hobbes, Confucius, and the Inca Manco Capac, Pufendorf asserts the Golden Rule: "Therefore all things whatsoever ye would that men should doe to you, doe ye even so to them" (Matt 7:12). Perhaps because he derives his concept of "lex charitatis" from natural equality, Pufendorf applies a test of reciprocity to the good for the Other. If in the Other's place one would not desire a particular good - colonial oppression, for example - one is neither authorized nor obliged to do that good for the Other. ${ }^{42}$ In contrast, Zebedaeus ignores the demand for reciprocity implicit in the Scriptural "lex proximi" to which he alludes - "Thou shalt love thy neighbor as thyself" (my emphasis; 
Luke 10:27) - and explicit in the Golden Rule. ${ }^{43}$ Not suprisingly, Pufendorf's commitment to natural equality and a test of reciprocity leads him to condemn explicitly the theory of natural slavery and the imposition of any good that the Other does not desire. ${ }^{44}$ As we can see, Dr. Wardell's appeal to Pufendorf in defense of colonial violence was as misguided as his appeal to Bacon. More importantly, Pufendorf's arguments demonstrate that even for seventeenthcentury legal theorists a common human society, love of neighbor, and natural law do not necessarily justify colonial aggression.

If, as we have seen, Bacon disagreed with Zebedaeus's conclusions and if certain seventeenth-century theorists disagreed with Zebedaeus's reasoning, what did Bacon think of the assumptions and premises from which Zebedaeus derived his conclusions? By postponing a discussion of divine law, Zebedaeus renders the law of nature and the law of charity fundamental premises of his argument $(208,215)$. As he deploys the "law of nature" and the "law of charity" in the Holy War Bacon signals his awareness that in seventeenth-century ideological discourse these two terms are semantically unstable. In The Advancement Bacon warns that "the great sophism of all sophisms... [is] equivocation, or ambiguity of words and phrase" (II $A$ of $L$ XIV. 7. II.) Such ambiguity is inherent in normal linguistic practice, since human beings understand and use words "according to the conceits and capacities of the vulgar sort." Due perhaps to the deleterious influence of the "vulgar sort," the "most general words" that "intervene in every inquiry" are often the most ambiguous. In the Holy War "charity" and "nature" prove to be such general, potentially ambiguous terms. ${ }^{45}$

In sixteenth and seventeenth-century England political and ideological pressures rendered the "law of nature" particularly susceptible to the ambiguity that, according to Bacon, plagues all words and phrases. J.P. Sommerville observes, "There was very wide agreement among [late sixteenth and early seventeenth-century] Englishmen on the existence of natural law inscribed by God in the hearts of men and discoverable by reason." Such wide agreement rendered "natural law" a rhetorically potent term; consequently, various political theorists appealed to natural law to defend widely divergent contentions. The influential Frenchman Jean Bodin appealed to natural law to limit royal sovereignty. Conversely, England's Scottish king, James I appealed to natural law to justify royal absolutism. ${ }^{46}$ One commentator has observed that by the 1640s the law of nature "was fast becoming a transcendent principle of essentially emotional appeal. All groups regarded it as sanctioning their dearest political convictions."47 In the Holy War Bacon demonstrates the ambiguity of natural law. In Zebedaeus's voice he derives 
natural slavery from the law of nature, although, as we have seen, in the Case of the Post-Nati in his own voice Bacon derives natural liberty from the same concept.

In fact, Bacon appears to have recognized the potential ambiguity of natural law years before he wrote the Holy War. Even in the Post-Nati, where Bacon contends that natural law supports his argument, he exploits that support cautiously. He does assert that natural law is "more worthy" than positive law. But unlike such natural law theorists as Vitoria, Bacon does not contend that if a positive law conflicts with natural law, judges must invalidate the positive law. ${ }^{48}$ Instead, in such cases judges must interpret the positive law "strictly and hardly." If the case is "clarius luce [clearer than light]," judges can uphold a positive law that conflicts with natural law. In the Post-Nati, Bacon appears unwilling to invest ultimate authority in a concept as potentially ambiguous as natural law. In the Holy War he vindicates that unwillingness by demonstrating that colonialists can exploit the ambiguity of this term to justify the violent oppression of foreign peoples.

Although charity figures more prominently in Bacon's thoughts than does natural law, charity proves to be no less susceptible to ambiguity and redefinition. Bacon assigns crucial epistemological and ethical functions to charity: it exposes religious hypocrisy, since "hypocrites seek by a pretended holiness towards God to cover their injuries towards men." To convict a hypocrite, one need only "send him from the works of sacrifice, to the works of mercy." Since such hypocrisy often underlies calls for religious persecution, the laws of charity restrain religious violence. ${ }^{49}$ But are professions of charity free from hypocrisy?

At the outset of the Holy War, Bacon suggests that, like the pretence of piety, the pretence of charity can "cover...injuries towards men." Within the witty banter that opens this dialogue, Eupolis contends that Pollio resembles a self-contained microcosm, since he egocentrically "profess[es] and practic[e]s both, to refer all things" to himself. This is a harsh characterization, since according to Bacon "the corrupter sort of mere Politiques...refer all things to themselves." But rather than deny this characterization, Pollio presses Eupolis to describe "they that practice it [egocentrism], and profess it not." Eupolis answers that such hypocrites "are the less hardy, and the more dangerous" (192) ${ }^{50}$ From the outset of the Holy War, then, Bacon warns his readers that hypocritical charity is even more dangerous than honest egocentrism. Did Bacon wish his readers to apply this warning to Zebedaeus's professed charity? In its incomplete form the Holy War does not answer this question. 
Although Bacon provides no evidence that Zebedaeus's professions of charity are hypocritical, he provides abundant evidence that for such cultural Others as Turks and Amerindians those professions are dangerous. Zebedaeus's discourse demonstrates that skillful ideologists, whether hypocritical or sincere, can exploit the "ambiguity of words and phrase" to subvert the ethical and epistemological functions Bacon assigns to the laws of charity. Unless restrained by Pufendorf's test of charitable reciprocity, zealots can redefine the unholy sacrifice of "sanguinary persecutions" as an act of mercy and rebut the charge that they injure human beings as they serve God. In this way, Sepúlveda designates forced evangelization "a great work of charity." ${ }^{51}$ As the Holy War demonstrates, colonialists like Zebedaeus can exchange Justinian's natural liberty for Aristotle's natural slavery and can transform the laws of charity from restrictions upon religious violence to authorizations of colonial oppression.

\section{Hofstra University}

\section{Notes}

1. John Bonwick. The Last of the Tasmanians: The Black War of van Diemen's Land (London, 1870) 324. I am indebted to Lewis Hanke for this reference: Hanke. Aristotle and the Indians: A Study of Race Prejudice in the Modern World (London: Hollis and Carter, 1959) 101. On Robert Wardell and the Australian, see R. W. Giblin. The Early History of Tasmania, 2 vols. (Melbourne: Melbourne University Press, 1934) 2: 433.

2. Bacon's nineteenth-century editor, James Spedding is uniquely cautious and does not identify Bacon's views with Zebedaeus's. Instead, he contends that Zebedaeus's opinion "cannot be taken as representing Bacon's own" and anticipates that the interlocutors of a completed dialogue would have approved a war with the Turks on primarily secular rather than religious grounds. Francis Bacon. The Letters and the Life, ed. James Spedding. 7 vols. (London: Longmans, Green, Reader, and Dyer, 1868-74) 7: 367-71; Francis Bacon. The Works. ed. James Spedding. Robert Leslie Ellis, and Douglas Denon Heath. 15 vols. (Boston Taggard and Thompson, 1861) 13: 175-180.

3. Writing in 1589 , in response to the Marprelate controversy, Bacon observes that "a character of love is more proper for debates of this [religious] nature than that of zeal." In the Sacred Meditation "Of Imposture" (1597) Bacon contends that zeal and ecstasy characterize the public bearing of hypocrites and impostors, whereas mildness and sobriety characterize the public bearing of the truly devout, who reserve excess for their private conversations with God. In De Sapientia Veterum (1609) he argues that the myth of Diomedes represents the misfortune awaiting zealous religious persecutors. Bacon appears to have remained wary of religious zeal to the end of his career. In the 1625 Essay "Of Unity in Religion" he both alludes to his treatise "Certain Considerations touching the Better Pacification and Edification of the Church of England" and complains that "to certain zelants all speech of pacification is odious." When citing Kiernan's edition of the Essayes I have modernized the spelling, capitalization, and 
italicization, but I have retained the original punctuation. The Letters and the Life 1: 94; Works 13: 26-28, 126-128; 14: 90-91; Francis Bacon. The Essayes of Counsels, Civill and Morall. ed. Michael Kiernan (Cambridge, Massachusetts: Harvard University Press, 1985) 12-13.

In 1616, Bacon admonishes George Villiers, Duke of Buckingham, not to be overly indulgent with his pro-Catholic relatives, observing that "the true Protestant religion [of the Church of England] is settled in the golden mean; the enemies unto her are the extremes on either hand." In 1623, he further warns Buckingham to identify the reformist extreme cautiously, since not all those whom the Papists accuse of "Puritanism" are true extremists. In 1615, he insists that for himself, "I hope I should sooner go to my grave than [convert] to that [Papist] Church ...". The Letters and the Life 5: 165; 6: 32; 7: 449.

\section{The Letters and the Life 7: 436.}

5. All citations to the Holy War refer to Francis Bacon, An Advertisement touching an Holy War, Works, ed. James Spedding, Robert Leslie Ellis, and Douglas Denon Heath. 15 vols. 13: $173-218$.

6. Although A. Wigfall Green initially seems to consider the pro-Zebedaean reading self-evident, he moderates his position in a later discussion of the Holy War and observes, "How far Bacon would have gone in justifying war had the work been completed is uncertain." Jerry Weinberger, who has written on the New Atlantis and The Advancement of Learning, also advances a pro-Zebedaean reading. He analyzes the relationship between the Holy War and Bacon's other texts and proposes a general hypothesis concerning the author's corpus. He contends, "Bacon's writing....always has two surfaces plus what is beneath...Each text is open to what is beneath it as a text and then again is open to the project described in the Great Intuaration and what is beneath that description." Unlike Weinberger, I am concerned with a single level of Bacon's text, which I believe Weinberger would consider its first, perhaps most superficial surface. I do agree with Weinberger, however, that the Holy War is intimately related to Bacon's other works and that those works form a more or less consistent whole. I feel justified therefore to expect that the surface level of the Holy War will cohere with the surface levels of Bacon's other works. By contrast, Weinberger's reading, which, for example, envisions Bacon discarding Protestantism in favor of Catholicism, denies the Holy War such consistency with the surfaces of Bacon's other texts. Patrick, "Hawk versus Dove: Francis Bacon's Advocacy of a Holy War by James I against the Turks," Studies in the Literary Imagination 4 (19741): 159-71; Green. Sir Francis Bacon: His Life and Works (Denver: Allan Swallow, 1952) 259-61; Green. Sir Francis Bacon 162; Weinberger, “On Bacon's Advertisement touching a Holy War," Interpretation: A Journal of Political Philosophy 9 (1981) 191-206; Weinberger, "Science and Rule in Bacon's Utopia: An Introduction to the Reading of the New Atlantis," American Political Science Review 70 (September 1976); 865-85; Weinberger. Science, Faith, and Politics: Francis Bacon and the Utopian Roots of the Modern Age: A Commentary on Bacon's Advancement of Learning (Ithaca: Cornell University Press, 1985).

7. Patrick 168.

8. The Letters and the Life 6: 178 
9. Patrick 160, 171.

10. The Letters and the Life 6: 158.

11. About a year and a half before the 1617 briefing, Bacon observed that the rumor of a Spanish match might coerce the virulently anti-Spanish Parliament to pass subsidies in order to prevent the monarchy from seeking financial relief in the arms of Spain. After the briefing, he worried about the match's unpopularity in Parliament and warned James I that any dissension within the Privy Council would embolden expressions of that unpopularity. In 1619, after the outbreak of the Thirty Years War, Bacon questioned the benefits of a marriage alliance, contending, "He [Phillip III] holds league with none but to have the nearer access to do harm by; and a match in kindred shall not hinder it when he intends his advantage once" (my emphasis). After his impeachment, Bacon refuses to opine concerning the match. However, he assumes that Buckingham opposes it, and he counsels the Duke to voice his honest objections. The Letters and the Life 5: 185; 6: 170-72; 7: 26, 499.

12. Spedding bases his account of these events on primary texts and on Samuel R. Gardiner's History of England. The Letters and the Life 6: 144-59. For a recent edition of Gardiner, see History of England from the Accession of James I to the Outbreak of the Civil War 1603-1642. 10 vols. (New York: AMS Press, 1965).

13. In 1592 and again in 1619 , Bacon charged that the Spanish used projected wars against the Turks to disguise military preparations against Christian states. Bacon specifically cites troop levies in Germany in 1592. Geoffrey Parker explains that during the early 1590 s conflict in Hungary between the Hapsburg and Ottoman empires coincided with Spanish intervention in the religious wars in France; consequently, the Hapsburgs were forced to levy troops for service in both theaters. Apparently, Bacon imagined that Hapsburg hypocrisy underlay this coincidence of international conflicts. The Letters and the Life 1: 186, 7: 26; Geoffrey Parker. The Army of Flanders and the Spanish Road (Cambridge: Cambridge University Press, 1972) 42.

14. For a discussion of the Pax Hispanica, see H. R. Trevor-Roper, "Spain and Europe 1598-1621, "The Decline of Spain and the Thirty Years War, ed. J.P. Cooper, vol. 4 of The New Cambridge Modern History (Cambridge: Cambridge University Press, 1970), 260-82.

15. Based on internal evidence, Spedding estimates that Bacon composed the relevant text, "A Short View to be Taken of Great Britain and Spain" in 1619. The Letters and the Life 7: 16-28.

16. In a draft of a royal proclamation calling a parliament, Bacon recommends that the English prepare to wage war in the Palatinate even as their diplomats in Spain negotiate for its recovery. The Letters and the Life 7: 124-28.

18. Bacon's most valuable theoretical accounts of religious war appear in Essay III "Of Unity in Religion," Essay XXIX "Of the True Greatness of Kingdoms and Estates," and Considerations touching a War with Spain. Bacon composed all three of these texts within three years of the Holy War and all but Essay III within two years. It seems probable, then, that these texts express views Bacon held when he composed the Holy War. Based on manuscript evidence, Spedding dates the Holy War to the summer of 
1622. Internal evidence tends to confirm Spedding's estimate, since Bacon clearly sets the dialogue in the year 1621. The interlocutor's discussions could have taken place no later than 1621, since Martius notes that the battle of Lepanto (1571) has occurred within the past fifty years, and no earlier than 1621 , since Gamaliel cites the premature passing of Philip III of Spain, who died that year. Spedding also reasons that Bacon composed the Considerations touching a War with Spain while the Commons debated war policy in March 1624. The Letters and the Life 7: 370, 460-68.

Bacon did not publish the final and most complete versions of Essays III and XXIX until 1625. However, the 1612 essay "Of Religion" repudiates religious violence at least as forcefully as its later redaction. Bacon did include the relevant passage from Essay XXIX in De augmentis scientiarum $(8,3)$, the Latin redaction of The Advancement. The translation of The Advancement was in progress in June 1622 when Bacon wrote that he anticipated its completion by the end of that summer, and De augmentis appeared in print the following year. The Letters and the Life 7: 375-77.

19. In Essay XXIX Bacon again contrasts Christian and Islamic theories and practices. He observes that human beings' innate sense of justice prevents them from embracing war and its calamities without at least a pretense of just cause. Consequently, to secure the supports of soldiers, taxpayers, and allies, the leaders of expansionist states must foster laws and customs that readily identify just occasions for war. "The Turk," he observes, "hath at hand, for cause of war, the propagation of his law or sect [Islam]; a quarrel that he may always command." Although Bacon observes that Christian states can find just causes of war in abuse offered to allies, "borderers, merchants, and politique ministers," he does not contend that Christians, like Turks, can command a religious "quarrel" to justify their wars. We can infer, then, that the laws and customs of Christian states do not justify offensive religious war. Bacon also posits an Islamic sanction for offensive religious war in "The Charge of Owen" and Considerations touching a War with Spain. Essayes 14, 96; The Letters and the Life 5: 158, 166; 7; 470, 475. The Islamic position on religious war appears to be more complex that Bacon acknowledges. Relevant passages in the Koran authorize defensive rather than offensive war (Sura, II, 185-190). See Moulavi Cherágh Ali, A Critical Exposition of the Popular "Jihad" (Karachi: Karimsons, 1977).

20. The Letters and the Life 6: 21; 7:472. Bacon restated his opposition to violent colonization late in his career, when he again repudiated extirpation of natives in Essay XXXIII “Of Plantations" (1625). In this text, however, he does not address colonizers' religious pretensions. Essayes 106.

21. Bacon's opposition to religious war and violent religious persecution appears to have been longstanding. As early as 1609 in De sapientia veterum he observes that religious violence, like "almost every king of violence... is in the end unprosperous" (omnis fere violentia...sub finem improspera est). Works 13: 27, 128.

22. In this lengthy legal opinion delivered in Calvin's Case, Bacon argues that Scots born after James I's accession to the English throne should be naturalized as English citizens Works 15: 189-247.

23. Earlier in the Post-Nati, as he discusses the power of a pater familias, Bacon parenthetically cites Aristotle's theory of natural servitude: the head of a household who governs "over his servants by prerogative of virtue and providence (for he that is able 
of body, and improvident of mind, is natura servus) is the very model of a king." Notably, in this passage Bacon translates the Latin servus as "servant" rather than as "slave", as employee rather than as property. He reinforces this translation in the next paragraph as he identifies the shepherd as another model for the king, precisely because the shepherd feeds and governs his sheep but does not own them. Bacon insists, "[Nor] are kings proprietaries or owners of the people: for God is sole owner of people." If God is the sole owner of people, the head of a household may govern employees as his servants but may not own them as his slaves. By alluding to Aristotle in this passage, Bacon asserts the naturalness of social and political hierarchy rather than the naturalness of institutional slavery. Works 15: 197-98.

24. The Letters and the Life 1: 137; Essayes 89-95.

25. Works, 14: 51. Arnold Williams examines the Renaissance exegesis of the relevant passages in Genesis in The Common Expositor: An Account of the Commentaries on Genesis 1527-1633 (Chapel Hill: University of North Carolina Press, 1948) 72-75, 133-34.

26. For a discussion of the seventeenth-century significance of this Baconian definition of the scientific project, see Charles Webster. The Great Instauration: Science, Medicine, and Reform 1626-66 (London: Duckworth, 1978) esp. 1-27. Christopher Hill also discusses the influence of Bacon's definition of the scientific project in Intellectual Origins of the English Revolution (Oxford: Clarendon, 1965) 85-130.

27. At the conclusion of the Novum Organum Bacon asserts, "Homo enim per lapsum et de statu innocentiae decidit, et de regno in creaturas" (Man at the same time fell from the state of innocency and from his dominion over creation: Spedding translation). Again in Valerius terminus he designates the true function of knowledge "a restitution and reinvesting (in great part) of man to the sovereignty and power... which he had in his first state of creation." Works 1: 538-39; 8: 350; 6: 18-20, 34.

28. Essayes 97 . In Bacon's early dramatic entertainment Gesta grayorum (1594) a character "advising the study of philosophy," insists that "the most innocent and meriting conquest... [is] the conquest of the works of nature." Again in Valerius terminus and the Novum organum (I NO CXXIX) Bacon designates the scientific conquest of nature the noblest human ambition. In the Proem to De interpretatione naturae (c. 1603) he argues that the philosopher who develops a scientific method capable of unlocking the secrets of the world would be "the propagator of man's empire over the universe, the champion of liberty, and the conqueror and subduer of necessities" (Spedding translation). The Letters and the Life 1: 334, 3: 85; Works 1: 335-38; 6: 36; 8: 160-163.

29. In the Preface of the Instauratio magna (1620) Bacon beseeches God "through my hands to endow the human family with new mercies" (my emphasis; Spedding translation). In Valerius terminus he observes that international communication through commerce and navigation supports scientific progress. Works 6: 29; 8: 35.

30. Although Eusebius, Gamaliel, and Eupolis offer few substantive remarks, the three remaining interlocutors, Pollio, Martius, and Zebedaeus, all express some views that conform to Bacon's and others that conflict with is. For example, Bacon agrees with Martius's charge that love of gold rather than love of God motivated the Spanish conquest of America. He also agrees with Zebedaeus's uncharacteristically moderate 
assertion that Christians' methods of propagating the faith must respect pagans' humanity (Essay III). The Letters and the Life 7: 503; Works 13: 196, 205; Essayes 14.

31. Works 6: 127-28, 228-31; Weinberger, "On Bacon's Advertisement" 200.

32. In the 1612 essay "Of Religion" Bacon asserts "But yet the bonds of religious unity are to be strengthened, as the bonds of human society be not dissolved". In he 1625 Essay III, he observes that "men must beware, that in the procuring... of religious unity, they do not dissolve and deface the laws of charity, and of human society" and insists that they do not dash the first table of the Decalogue, which defines their duty to God, against the second, which defines their duty to other human beings. Essayes 11, 14.

33. Tzvetan Todorov. The Conquest of America, trans. Richard Howard (New York: Harper, 1984) 42-43; Stephen Greenblatt, "Learning to Curse: Aspects of Linguistic Colonialism in the Sixteenth Century," First Images of America: The Impact of the New World on the Old. ed. Fredi Chiapelli, 2 vols. (Berkeley: University of California Press, 1976) 2: 561-80.

\section{Todorov 153-55.}

35. For an analysis of the history and significance of this application of Aristotle's theory of natural slavery, see Lewis Hanke. Aristotle and the Indians.

The arguments Zebedaeus employs in the Holy War suggest that Bacon was familiar with the Valladolid debate between Sepúlveda and Bartolomé de Las Casas (1550-51). Although neither of the two texts most relevant to that debate, Sepúlveda's Democritus alter and Las Casas's Apologia, were published during the sixteenth or seventeenth centuries, many of Las Casas's other texts were widely published. Samuel Purchas published a summary of the Valladolid debate in 1603. Bacon also may have encountered this application of Aristotle's theory of natural slavery in De Indis noviter inventis, where Francisco de Vitoria examines and rejects Europeans' claims to natural dominion over Amerindians. Lewis Hanke. The Spanish Struggle for Justice in the Conquest of America (Philadelphia: University of Pennsylvania Press, 1949) 133-46; Samuel Purchas. Hakluytus Posthumus, or Purchas His Pilgrimage. 18 vols. (Glasgow: James MacLenose, 1906) 18: 176-80; Francisco de Vitoria. De Indis et De Ivre Belli Relectiones. ed. Ernest Nys. The Classics of International Law (Washington, D.C.: Carnegie Institution of Washington, 1917). 1: 24, 335. I have cited Vitoria's Relectiones according to their numbered sections.

36. Martius cites deficiencies in Turkish letters, arts, and sciences, a social structure that lacks a gentry or nobility, and a family life that lacks "natural affection" and care for children. Bacon appears to have accepted at least some of these inaccurate characterizations of Turkish culture. In the Essayes he contends that Turks are "a cruel people," despise marriage, and lack an aristocracy (Essays VIII, XII, and XIII). Bacon may have based some of Martius's charges on Ogier Ghiselin de Busbecq's Turkish Letters. Busbecq, whom Bacon cites in the Essayes, describes Ottoman dynastic bloodshed and the lack of a hereditary aristocracy and of a sense of chronology among the Turks. In his 1529 treatise On War Against the Turk Martin Luther also described the deficiencies in Turkish family life, social structure, and inheritance practices. For a more accurate account of Ottoman technology, learning, and social structure, see Halil Inalcik, The Ottoman Empire: The Classical Age 1300-1600, trans. Norman 
Itzkowitz and Colin Imber (New York: Praeger, 1973) 140-78. Essayes 26, 39, 41; Works 13: 198-99; Olgier Ghiselin de Busbecq, The Turkish Letters. trans. Edward Seymour Forster (Oxford, Clarendon, 1927) 23, 30, 55; Martin Luther, Works, ed. Helmut T. Lehman and Jaroslav Pelikan. 55 vols. (Philadelphia: Fortress Press, 1976) 46: 181-83.

37. Lewis Hanke. All Mankind is One (De Kalb: Northern Illinois University Press, 1974) 82-98; Works 13: 216.

38. Samuel Purchas relates such an argument in his summary of the Valladolid debate between Sepúlveda and Bartolomé de Las Casas, "But we may more truely say, that the Spaniards during their abode in the Indies, have yeerely sacrificed to their so deerely beloved and reverend Goddesse Coveteousnesse more people, than the Indians have done in a hundred yeeres." Purchas 18: 179-80.

39. The Letters and the Life 6: 21.

40. Works 6: 313-14; Essayes 39.

41. Samuel Pufendorf. De Jure Naturae et Libri Octo. trans. C.H. Oldfather and W. A. Oldfather, 2 vols. (Oxford: Clarendon, 1934) 2. 3. 15. I have cited Pufendorf's De Jure Naturae according to its numbered books, chapters, and sections.

42. Pufendorf, 2. 3. 13, 3. 2. 1.

43. Through references to the Samaritan and the Levite, Zebedaeus clearly alludes to the formulation of "lex proximi" that precedes the parable of the Good Samaritan. The Holy Bible: a Facsimile in a Reduced Size of the Authorized Version Published in the Year 1611, ed. A. W. Pollard (Oxford: Oxford University Press, 1911).

44. Pufendorf, 3. 2. 8. Bacon too seems to have opposed the imposition of a good the Other does not desire. Although he insists repeatedly, "In charity, there is no excess," in Essay XIII he acknowledges that "[e]rrors, indeed, in this virtue of goodness, or charity, may be committed." He characterizes one such error by alluding to one of Aesop's fables: "Neither give thou Aesop's cock a gem, who would be better pleased, and happier, if he had had a barley-corn" (Essay XIII). Here the error is to do the Other a good that he or she does not recognize or desire. Works 6: 342-45; Essayes 39.

45. Works 6: 279-80.

46. In Les six livres de la republique Jean Bodin argues that natural and divine law require kings to keep their contracts and forbid them to kill or steal. James I claims to ground his Trew Law of Free Monarchies (1598) upon natural law as well as upon scripture and fundamental positive laws. From these grounds he argues that "the King is aboue the law, as both the author and giuer of strength thereto." A king conforms himself to the law due to his goodness and not due to any restraint that positive law can impose upon him. I am indebted to George L. Mosse for these references. For a discussion of Bodin's influence in England, see Mosse. The Struggle for Sovereignty in England: From the Reign of Queen Elizabeth to the Petition of Right (New York: Octagon Books, 1968) 32-41. J. P. Sommerville. Politics and Ideology in England 1603-1640 (London: Longman, 1986) 15; James I. The Political Works, ed. Charles Howard McIlwain (New York: Russell and Russell, 1965) 54, 63; Jean Bodin. The Six Bookes of a Common- 
weale: A Facsimile Report of the English Translation of 1606, ed. Kenneth Douglas McRae (Cambridge, Massachusetts: Harvard University Press, 1962) 1. 8. 2. 2. I have cited Bodin's La Republique according to its numbered books and chapters.

47. Merritt Y. Hughes. Introduction, 1648-49. Vol. 3 of Complete Prose Works of John Milton. 8 vols. (New Haven: Yale University Press, 1962) 68.

48. Works 15: 202, 226. Vitoria asserts, "And if there were any human law which without any cause took away rights conferred by natural and divine law, it would be inhumane and unreasonable and consequently would not have any force of law." Although the phrase "without any cause" significantly qualifies Vitoria's assertion, Bacon does not express even such qualified willingness to invalidate positive law in light of natural law. Vitoria 3. 2. 388.

49. Works 14: 89-90. At the conclusion of Essay III, Bacon observes, "And it was a notable observation of a wise father...: That those, which held and persuaded, pressure of consciences, were commonly interessed therein, themselves, for their own ends." Essayes 14-16.

50. Works 6: 112-13, 317-19. Bacon discusses egocentrism at length in Essay XXIII, Essayes 73.

51. Columbia University. Introduction to Contemporary Civilization in the West: A Source Book. 3rd ed. 2 vols. (New York: Columbia University Press, 1960) 1: 529. 